\title{
Finland HF and Esrange MST radar observations of polar mesosphere summer echoes
}

\author{
T. Ogawa ${ }^{1}$, N. F. Arnold ${ }^{2}$, S. Kirkwood ${ }^{3}$, N. Nishitani ${ }^{1}$, and M. Lester ${ }^{2}$ \\ ${ }^{1}$ Solar-Terrestrial Environment Laboratory, Nagoya University, 3-13 Honohara, Toyokawa, Aichi 442-8507, Japan \\ ${ }^{2}$ Department of Physics and Astronomy, University of Leicester, University Road, Leicester, LE1 7RH, UK \\ ${ }^{3}$ Swedish Institute of Space Physics, Box 812, S-981 28 Kiruna, Sweden
}

Received: 12 April 2002 - Revised: 16 August 2002 - Accepted: 1 October 2002

\begin{abstract}
Peculiar near range echoes observed in summer with the SuperDARN HF radar in Finland are presented. The echoes were detected at four frequencies of $9,11,13$ and 15 $\mathrm{MHz}$ at slant ranges of $105-250 \mathrm{~km}$ for about $100 \mathrm{~min}$. Interferometer measurements indicate that the echoes are returned from $80-100 \mathrm{~km}$ altitudes with elevation angles of $20^{\circ}-60^{\circ}$. Echo power $(\leq 16 \mathrm{~dB})$, Doppler velocity (between -30 and $\left.+30 \mathrm{~m} \mathrm{~s}^{-1}\right)$ and spectral width $\left(\leq 60 \mathrm{~m} \mathrm{~s}^{-1}\right)$ fluctuate with periods of several to $20 \mathrm{~min}$, perhaps due to short-period atmospheric gravity waves. When the HF radar detected the echoes, a vertical incidence MST radar, located at Esrange in Sweden (650 km north of the HF radar site), observed polar mesosphere summer echoes (PMSE) at altitudes of 80$90 \mathrm{~km}$. This fact suggests that the near range HF echoes are PMSE at HF band, although both radars did not probe a common volume. With increasing radar frequency, HF echo ranges are closer to the radar site and echo power becomes weaker. Possible mechanisms to explain these features are discussed.
\end{abstract}

Key words. Meteorology and atmospheric dynamics (middle atmosphere dynamics; thermospheric dynamics; waves and tides; instruments and techniques)

\section{Introduction}

Polar mesosphere summer echoes (PMSE) at northern high latitudes have been well studied using vertical incidence radars at VHF-UHF frequencies (see reviews by Cho and Kelley, 1993; Röttger, 1994; Cho and Röttger, 1997). Recently, vertical incidence HF systems (Karashtin et al., 1997; Kelley et al., 2002) and a dynasonde collocated with the EISCAT VHF radar (Lee et al., 2001; Liu et al., 2002) have also been utilized for PMSE observations. The Super Dual Auroral Radar Network (SuperDARN) HF radars at northern and southern high latitudes use oblique multiple beams to investigate the high latitude E- and F-region ionosphere (Greenwald

Correspondence to: T. Ogawa

(ogawa@stelab.nagoya-u.ac.jp) et al., 1995). These radars are also capable of measuring neutral winds in the upper mesosphere and lower thermosphere $(80-100 \mathrm{~km})$ by detecting meteor echoes (Hall et al., 1997; Jenkins and Jarvis, 1999; Arnold et al., 2003).

The first HF radar observations of Antarctic upper mesosphere summer echoes, being different from meteor echoes, have been recently reported by Ogawa et al. (2002) who analyzed 11-MHz SuperDARN radar data from Syowa Station, Antarctica $\left(69.0^{\circ} \mathrm{S}, 39.6^{\circ} \mathrm{E}\right)$. They showed that near range $(180-315 \mathrm{~km})$ echoes were characterized by a duration of less than $80 \mathrm{~min}$, quasi-periodic oscillations of Doppler velocity and echo power with periods of 5-20 min, velocities between -40 and $+20 \mathrm{~m} \mathrm{~s}^{-1}$ and narrow spectral widths less than $40 \mathrm{~m} \mathrm{~s}^{-1}$. They then concluded, without other supporting evidences, that these echoes were well explained by the PMSE hypothesis. Data analyzed by them were obtained during the normal SuperDARN operation ("common" mode: first range gate of $180 \mathrm{~km}$, range resolution of $45 \mathrm{~km}$ and time resolution of $2 \mathrm{~min}$ ) to detect ionospheric echoes. However, the common mode parameters, in particular, the first range gate and the range resolution, are not always suitable for the detailed study of PMSE that usually appear within altitudes of $80-90 \mathrm{~km}$. To confirm that HF radars like SuperDARN can detect PMSE and to investigate generation mechanisms of oblique HF-PMSE, more sophisticated observations coordinated with other instruments have been required.

In this paper, we examine in detail near range upper mesosphere echoes observed with an HF radar in Finland (one of the SuperDARN radars) on 8 August 1999. The HF echoes are compared with PMSE detected on the same day with a mesosphere-stratosphere-troposphere (MST) radar in Sweden to demonstrate that oblique incidence HF radars are suitable for the PMSE study.

\section{Observations}

Echoes on which we focus in this paper were observed with the CUTLASS HF radar at Hankasalmi $\left(62.3^{\circ} \mathrm{N}, 26.6^{\circ} \mathrm{E}\right)$ in Finland and a $52-\mathrm{MHz}$ MST radar at Esrange $\left(67.6^{\circ} \mathrm{N}\right.$, 


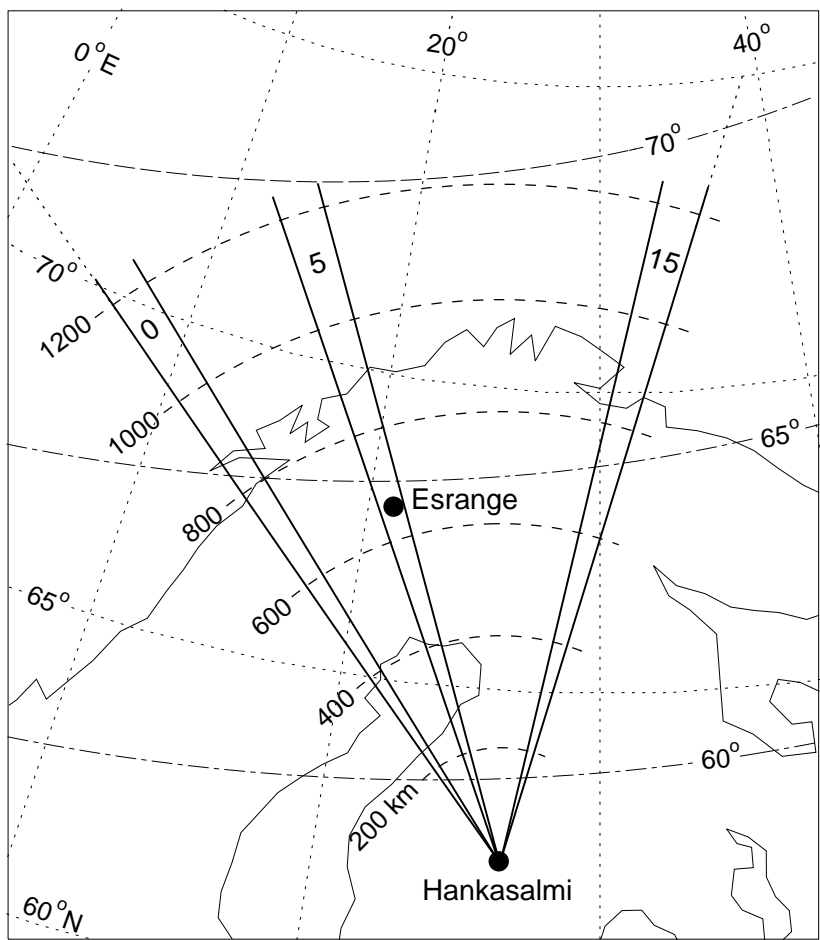

Fig. 1. Field of view of the Finland HF radar, covered with 16 narrow beams (beam numbers $0,1,2, \ldots, 15$ ), located at Hankasalmi. Beam 5 looks toward Esrange in Sweden where the ESRAD radar is located. Geomagnetic latitudes and ground ranges from Hankasalmi are indicated by dot-dashed and dashed curves, respectively.

$21.0^{\circ} \mathrm{E}$ ), called the ESRAD radar, in Sweden (Chilson et al., 1999). Figure 1 shows the field of view (FOV) of the HF radar in geographic coordinates. The FOV is covered with 16 narrow beams (beam numbers $0,1,2$, ldots, 15 ; each beam width $\sim 3.5^{\circ}$ ) over an azimuth sector of $52^{\circ}$. Beam 5 looks toward Esrange, about $650 \mathrm{~km}$ from Hankasalmi, where the ESRAD radar is located.

On 8 August 1999, the Finland radar was operated in a special mode to investigate detailed meteor echo characteristics and neutral winds (Arnold et al., 2003); that is, the radar emitted sequentially four frequencies close to $9,11,13$ and $15 \mathrm{MHz}$. At each frequency, the radar beam was scanned from beam 15 to 0 for about $35 \mathrm{~s}$ with a range resolution of $15 \mathrm{~km}$ and the first range gate of $60 \mathrm{~km}$. On this day, the ESRAD radar, having nearly vertical beams, performed routine observations of echo power and three dimensional velocity of scatterers over Esrange with time and altitude resolutions of $4 \mathrm{~min}$ and $300 \mathrm{~m}$, respectively.

The upper panel in Fig. 2 displays time and slant range distributions of the echo power, observed at four frequencies on eight beams (beams 1, 3, ., 15), of the Finland radar from 09:00 to 12:00 UT. In addition to meteor echoes appearing sporadically in range and time, a cluster of echoes is seen on all the beams; these exist mainly at $105-135 \mathrm{~km}$ ranges from 09:40 to 10:40 UT, and shift to later hours with increasing beam number, meaning the eastward movement of the echo region (see Fig. 1).

The lower panel in Fig. 2 shows the distribution of the echo power observed at altitudes of $80-90 \mathrm{~km}$ with the ESRAD radar. Clear PMSE appear first at around 09:45 UT at $89 \mathrm{~km}$. The echo altitudes decrease with a rate of about 1.2 $\mathrm{m} \mathrm{s}^{-1}$ due to semi-diurnal tide (Williams et al., 1995), reach $85 \mathrm{~km}$ at around 10:40 UT and thereafter are almost stationary until 11:40 UT when the echoes disappear. The vertical extent of the echo region is about $5 \mathrm{~km}$. The echo powers vary in time and altitude with short periods, perhaps caused by short-period atmospheric gravity waves (Williams et al., 1989; Rüster et al., 1996). Unfortunately, the echo powers are too weak to show detailed variations of the velocity components. From close inspection, however, we see that the vertical velocities below $88 \mathrm{~km}$ are less than $-2 \mathrm{~m} \mathrm{~s}^{-1}$, being consistent with the downward motion $\left(-1.2 \mathrm{~m} \mathrm{~s}^{-1}\right)$ of the echo region.

A comparison between the upper and lower panels in Fig. 2 indicates that the HF echoes at 105-135 km between 09:40 and 10:40 UT are coincident with the ESRAD PMSE and though the HF and ESRAD radar sites are $650 \mathrm{~km}$ apart, thus suggesting the HF echoes to be PMSE at HF band.

To investigate detailed characteristics of the HF echoes, Fig. 3 shows time and slant range distributions of the echo power observed at $9,11,13$ and $15 \mathrm{MHz}$ on beam 5 that looks toward Esrange. At $9 \mathrm{MHz}$, although meteor echoes are randomly distributed, a cluster of strong echoes (8-16 $\mathrm{dB})$ appears at ranges of 105-225 km between 09:25 and 11:00 UT. At $11 \mathrm{MHz}$, the strong echo region $(6-14 \mathrm{~dB})$ is limited to within $105-120 \mathrm{~km}$ and around $200 \mathrm{~km}$ at about 10:30 UT. At 13 and $15 \mathrm{MHz}$, the echo regions with weak powers $(\leq 10 \mathrm{~dB})$ are mostly limited to within $105-135 \mathrm{~km}$. Thus, the echo range and power are wider and stronger, respectively, with decreasing radar frequency.

Figure 4 displays distributions of the echo power observed at 9 and $15 \mathrm{MHz}$ on eight beams between 09:00 and 12:00 UT. At $9 \mathrm{MHz}$, the strong echo regions appear between 105 and $250 \mathrm{~km}$ from 09:20 UT (beam 1) until 11:30 UT (beam 15), during which time the ESRAD PMSE occurred (Fig. 2). With time, the echo ranges tend to shift toward the radar site at early hours and away from it at later hours. The echo region shifts slowly toward later hours with increasing beam number, as also seen in Fig. 2. At $15 \mathrm{MHz}$, weak echoes $(\leq 10 \mathrm{~dB})$ exist at 105-135 km and between 09:40 and 10:40 UT during which time the ESRAD PMSE region moves downward (Fig. 2). With increasing beam number, the echo region also shifts slowly toward later hours without changing the echo ranges.

It is estimated that the vertical pattern of the SuperDARN antenna array is quite broad with an average half power beamwidth of $\sim 30^{\circ}$ (Greenwald et al., 1985). At $8 \mathrm{MHz}$, the sensitivity maximizes at an elevation angle (EL) of $35^{\circ}$ whereas, at $20 \mathrm{MHz}$, this EL decreases to $15^{\circ}$. This means that the Finland HF radar has a maximum gain at about $\mathrm{EL}=33^{\circ}$ at $9 \mathrm{MHz}$ and $\mathrm{EL}=23^{\circ}$ at $15 \mathrm{MHz}$ (Arnold et al., 2003). The sensitivity at EL's larger than $60^{\circ}$ is believed to 
Finland Echo Power $(9,11,13,15 \mathrm{MHz}) \quad$ August 8, 1999
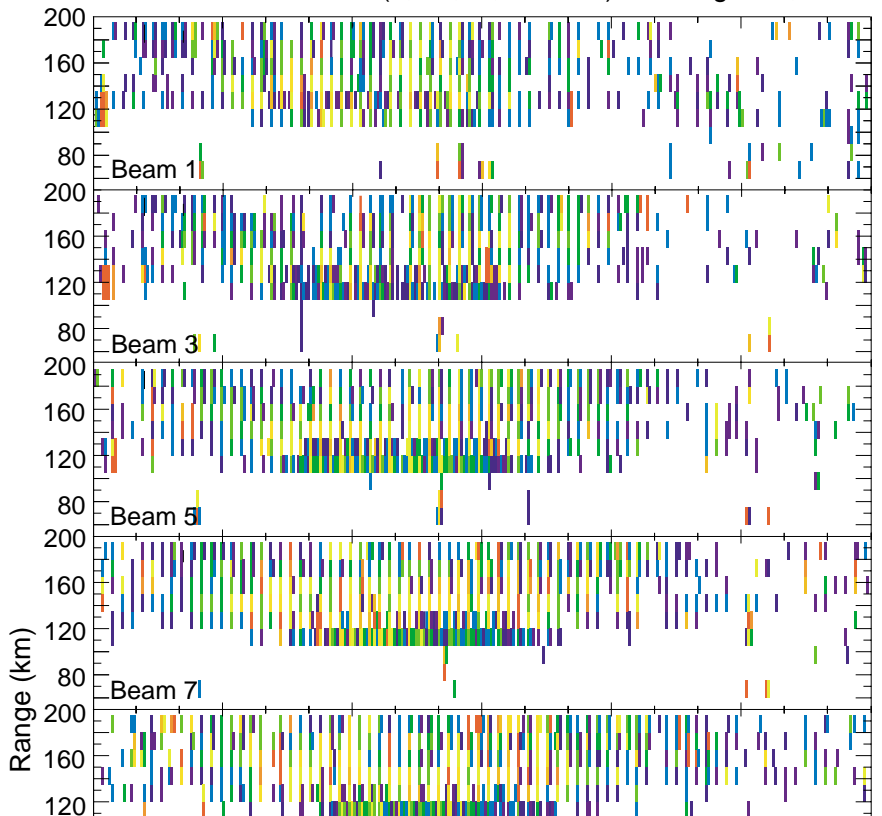

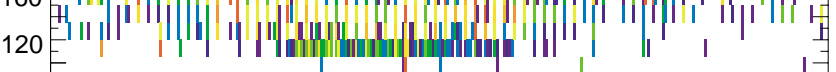
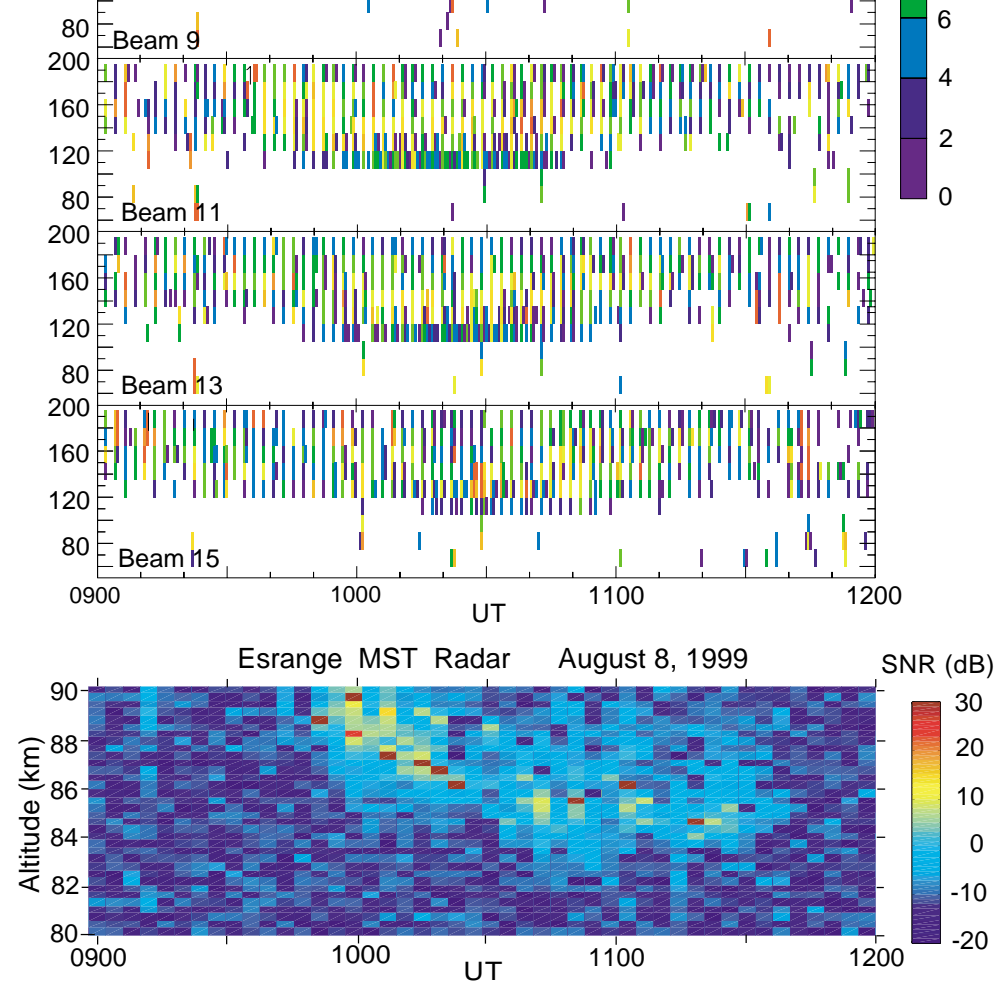

Fig. 2. (Upper) Time and slant range distributions of echo power observed at four frequencies on eight beams (beams $1,3, \ldots, 15)$ of the Finland HF radar, and (lower) time and altitude distribution of echo power observed with the ESRAD radar between 09:00 and 12:00 UT on 8 August 1999. be extremely low, being the reason why the HF radar could not detect echoes at ranges of $60-105 \mathrm{~km}$ (Fig. 2). Now we assume that HF echoes return from altitudes of 80-90 km (ESRAD-PMSE altitudes) without wave refraction during propagation. Then the observed slant ranges of $105-250 \mathrm{~km}$ at $9 \mathrm{MHz}$ correspond to EL's of $19^{\circ}-59^{\circ}$, within which the radar beam at $9 \mathrm{MHz}$ has the maximum gain. Similarly, EL's are between $36^{\circ}$ and $59^{\circ}$ for the observed ranges of 105-135 $\mathrm{km}$ at $15 \mathrm{MHz}$; these angles, however, are deviated from the angle $\left(23^{\circ}\right)$ with the maximum gain at $15 \mathrm{MHz}$, resulting in the weak echo power at $15 \mathrm{MHz}$ as shown in Fig. 4. Actually, the $15 \mathrm{MHz}$ antenna pattern has a secondary gain peak at $64^{\circ}$ that is $8 \mathrm{~dB}$ down (two way of transmitting and receiving) from the main peak at $23^{\circ}$. This secondary peak might also favor detecting the weak $15 \mathrm{MHz}$ echoes.

The Finland HF radar has a function of interferometry to measure angle-of-arrival of returned signal (Milan et al., 1997). Figure 5 shows contour maps of the echo occurrence 


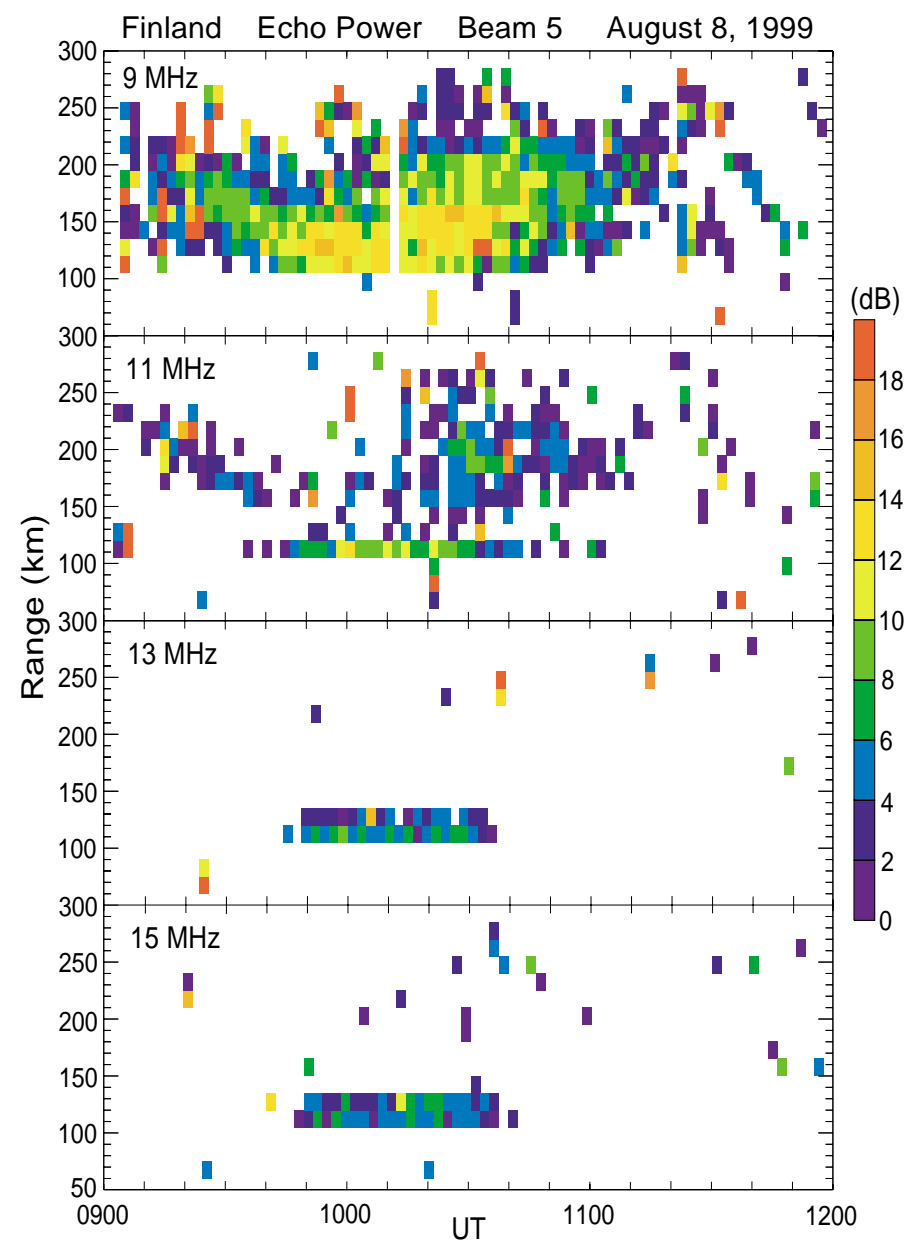

Fig. 3. Time and slant range distributions of echo power at 9, 11, 13 and $15 \mathrm{MHz}$ on beam 5 .

rate at four frequencies as a function of range and EL. To make these maps, we selected EL data with echo powers exceeding $20 \mathrm{~dB}$ (to avoid possible meteor echo contamination) during 08:00-12:00 UT and then sorted the data into bins (one bin has a range gate of $15 \mathrm{~km}$ and an EL of $1^{\circ}$ ) to perform a simple two-dimensional three-point smoothing of the data. The contour lines have intervals of 0.5 for $9 \mathrm{MHz}$ and 0.25 for other frequencies. The relation between range and EL for constant altitude ( $h=80,90$ and $100 \mathrm{~km})$ is represented by a dashed curve. Low occurrence rates at 13 and $15 \mathrm{MHz}$ are due to the high threshold of $20 \mathrm{~dB}$ in selecting the data. The 9 and $11 \mathrm{MHz}$ plots in Fig. 5 indicate that high occurrence rates exist between the curves of $h=80$ and 100 $\mathrm{km}$. The echoes at ranges beyond $250 \mathrm{~km}$ in these plots are not PMSE (see Fig. 3) but meteor echoes with powers above $20 \mathrm{~dB}$ that usually appear at $80-100 \mathrm{~km}$ altitudes. Also, the echoes beyond $140 \mathrm{~km}$ in the 13 and $15 \mathrm{MHz}$ plots are meteor echoes. It is noted that the interferometer is accurate to a few degrees, meaning that, for a range resolution of $15 \mathrm{~km}$, it is impossible to determine echo altitude with a resolution better than about $10 \mathrm{~km}$ (Arnold et al., 2003).

EL's shown in Fig. 5 do not always give true EL's of arrival because of $2 \pi$ ambiguity peculiar to an interferometer.
This ambiguity occurs when true EL's exceed a threshold and calculated EL's become lower than the true EL's. According to Milan et al. (1997), on the central beam of the Finland radar, the maximum EL (MEL) below which no ambiguity takes place is around $35^{\circ}, 32^{\circ}, 29^{\circ}$ and $27^{\circ}$ for $9,11,13$ and $15 \mathrm{MHz}$, respectively. This is the reason why no data points appear at EL's beyond these MEL's in Fig. 5. When returned signals have EL's higher than MEL's, aliasing occurs so that data are plotted at EL's lower than the true values; for example, the $9 \mathrm{MHz}$ rays with true EL's of $37^{\circ}, 40^{\circ}, 45^{\circ}$ and $50^{\circ}$ are misjudged as $12^{\circ}, 19^{\circ}, 28^{\circ}$ and $35^{\circ}$, respectively. These considerations suggest that most data existing in the left of the $h=80 \mathrm{~km}$ curve and also at ranges less than $200 \mathrm{~km}$ are aliased and should be placed at higher EL's beyond MEL's. If this is not the case, the echoes should return from altitudes below about $70 \mathrm{~km}$. Thus, we can conclude that almost all the echoes return from altitudes of $80-100 \mathrm{~km}$, are consistent with the ESRAD PMSE altitudes in Fig. 2 and also with meteor echo altitudes.

Time and slant range distributions of the line-of-sight Doppler velocity at 9 and $15 \mathrm{MHz}$ are displayed in Fig. 6 . Positive (negative) sign means motion toward (away) from the radar. It can be seen that the velocities fluctuate with 


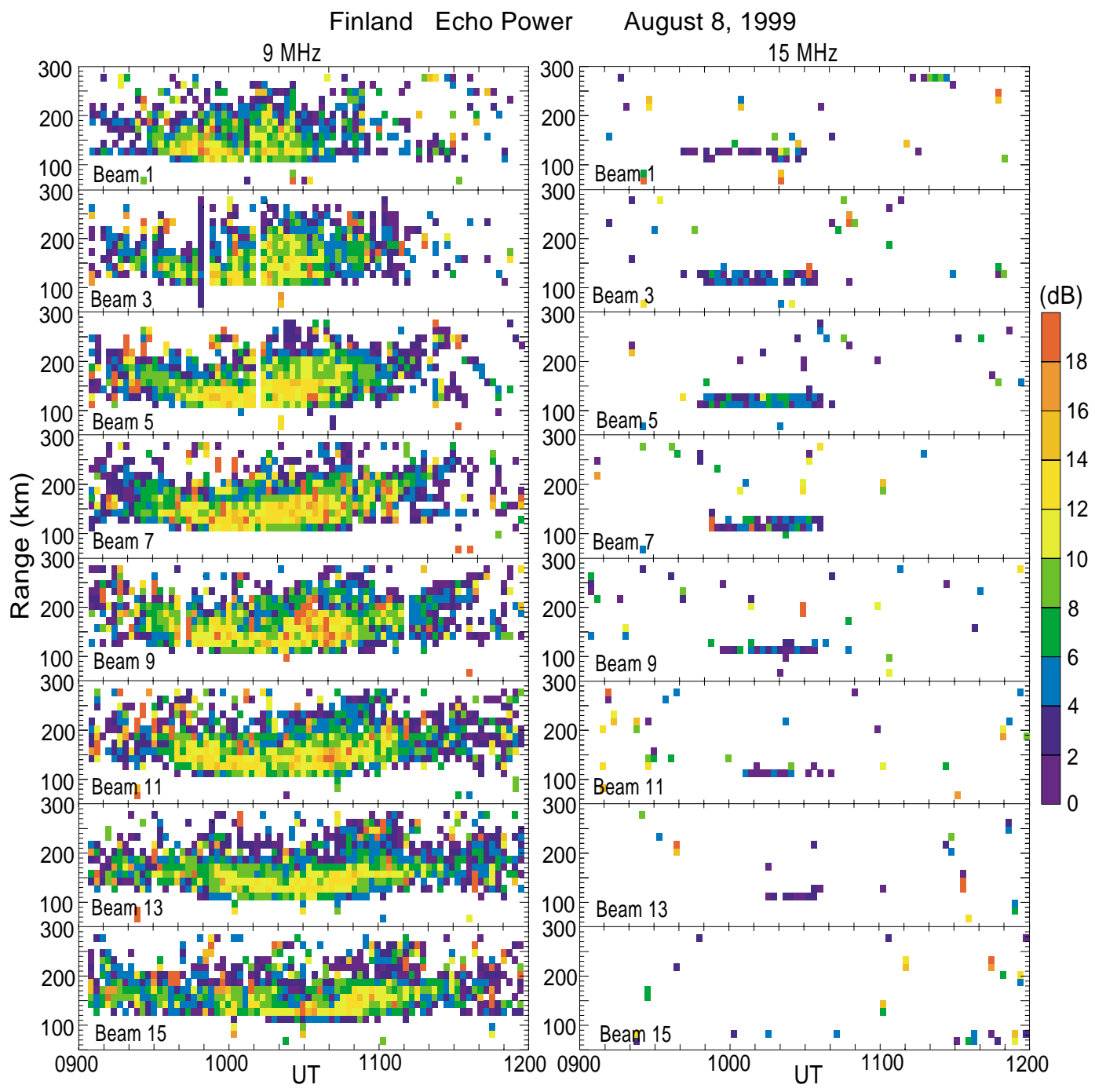

Fig. 4. Time and slant range distributions of echo power at (left) 9 and (right) $15 \mathrm{MHz}$ on eight beams (beams $1,3, \ldots, 15$ ).

magnitudes less than $\pm 30 \mathrm{~m} \mathrm{~s}^{-1}$. At $9 \mathrm{MHz}$, the velocities are predominantly northward (southward) before (after) about 10:00 UT, probably caused by tidal motion of neutral winds.

Time variations of the echo power, Doppler velocity and spectral width at four frequencies at the range gate of 105$120 \mathrm{~km}$ on beam 5 are plotted in Fig. 7 where the following is observed: (1) powers decrease with increasing frequency, (2) velocities are mostly within $\pm 20 \mathrm{~m} / \mathrm{s}$, (3) widths are less than $60 \mathrm{~m} \mathrm{~s}^{-1}$, which is characteristic of the widths of meteor echoes to derive neutral winds (e.g. Arnold et al., 2001, 2003), when the power is strong, (4) the power, velocity and width fluctuate with periods of several to $20 \mathrm{~min}$ and (5) no particular correlation among three parameters exists. It is noted that the echoes are often contaminated with sporadic meteor echoes so that the short period fluctuations (less than, say, $5 \mathrm{~min}$ ) of the three parameters do not always represent the PMSE-related fluctuations.

\section{Discussion}

The results are summarized as follows: (1) the Finland HF radar detected peculiar echoes at four frequencies at slant ranges of $105-250 \mathrm{~km}$ with EL's of $20^{\circ}-60^{\circ}$. (2) Angleof-arrival measurements of echoes indicates echo altitudes of $80-100 \mathrm{~km},(3)$ echo power $(\leq 16 \mathrm{~dB})$, Doppler velocity $\left(\leq \pm 30 \mathrm{~m} \mathrm{~s}^{-1}\right)$ and spectral width $\left(\leq 60 \mathrm{~m} \mathrm{~s}^{-1}\right)$ fluctuate with periods of several to $20 \mathrm{~min}$, (4) Echo ranges are 105$250 \mathrm{~km}$ at 9 and $11 \mathrm{MHz}$ while they are $105-135 \mathrm{~km}$ at 13 and $15 \mathrm{MHz}$ and power decreases with increasing frequency, (5) At the same time as when the HF echoes were detected, the ESRAD MST radar, located at $650 \mathrm{~km}$ north of the HF radar site, observed typical PMSE lasting for about $100 \mathrm{~min}$ at altitudes of 80-90 km over Esrange.

The above items 1 and 5 suggest that the HF echoes are categorized as PMSE. The echo altitudes (item 2) are consistent with previous vertical incidence HF radar observations (Karashtin et al., 1997; Kelley et al., 2002). 

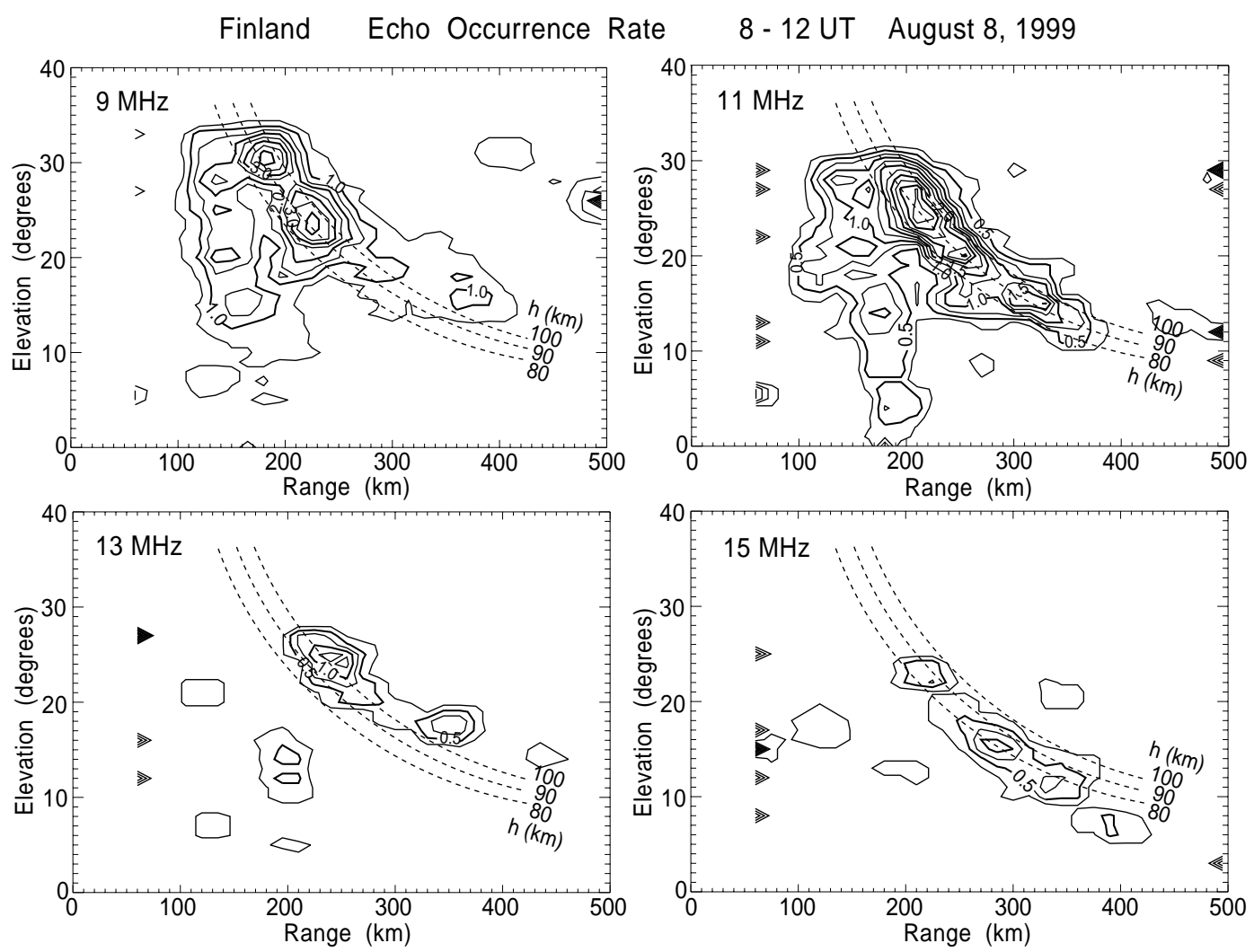

Fig. 5. Contour maps of echo occurrence rate at four frequencies as a function of range and elevation angle. Contour lines have intervals of 0.5 for $9 \mathrm{MHz}$ and 0.25 for other frequencies. Relation between range and elevation angle for constant altitude $(h=80,90$ and $100 \mathrm{~km})$ is represented by dashed curve.

The echo characteristics (item 3 ) together with the echo duration $(\sim 100 \mathrm{~min})$ are quite similar to those of upper mesosphere echoes detected at near ranges in summer with the SuperDARN radars $(\sim 11 \mathrm{MHz})$ at Syowa Station, Antarctica (Ogawa et al., 2002), supporting that the Syowa echoes were PMSE. Röttger (1994) summarized some important features of the Arctic PMSE observed with vertical incidence VHF radars as follows: (i) echoes are highly variable with typical temporal scales of $10 \mathrm{~s}$ to 5-20 min and their variations are barely correlated adjacent range gates separated by $1 \mathrm{~km}$, (ii) Vertical velocities oscillate up to \pm 5 $\mathrm{m} \mathrm{s}^{-1}$ with periods of 6-15 min and are not sinusoidal, (iii) echo amplitude variability is not clearly related to certain phases of the velocity oscillations, and (iv) spectral widths are extremely narrow but also large. Röttger (1994) suggested that short-period atmospheric gravity waves caused these features (e.g. Williams et al., 1989; Rüster et al., 1996) which seems to be the case for our observations too.

We speculate, from items 1 and 5, that the HF-VHF PMSE region extended over $550 \mathrm{~km}$, from over Esrange to $100 \mathrm{~km}$ north of the HF radar. Unfortunately, we have no information of the PMSE occurrence in between (over $400 \mathrm{~km}$ from Esrange to $250 \mathrm{~km}$ north of the HF radar) to confirm this. As shown in Figs. 2 and 4, the HF-PMSE appeared at ranges of $105-250 \mathrm{~km}$ on all the beams (item 1), which means that instantaneous zonal extension of the HF-PMSE region is at least $150-200 \mathrm{~km}$ (Fig. 1). For the Syowa HF radar case, the meridional extension is estimated to be at least 180-300 $\mathrm{km}$ (Ogawa et al., 2002). In the past, Bremer et al. (1996) reported PMSE structures having zonal extensions of more than $130 \mathrm{~km}$ (Andenes and Troms $\emptyset$ in Norway) and Kirkwood et al. (1995) studied those having meridional extensions of at least $200 \mathrm{~km}$ (Esrange and Troms $\varnothing$ ).

The current HF-PMSE were detected in oblique directions with EL's of $20^{\circ}-60^{\circ}$ (item 1) while the Syowa PMSE were observed at $15^{\circ}-30^{\circ}$ (corresponding to ranges of 180-315 $\mathrm{km})$. Previous VHF-UHF observations of PMSE utilized vertical (or nearly vertical) pointing beams because PMSE were believed to be strongest for a vertical beam with a very high aspect sensitivity (e.g. Zecha et al., 2001). Using a VHF radar, Czechowsky et al. (1988) found highly aspectsensitive echoes in the main vertical beam and non-aspectsensitive echoes with two grating lobes at EL's of $52^{\circ}$ and $55^{\circ}$; they suggested that there was a transition from dominant quasi-specular to more isotropic backscattering with increasing off-zenith angle. Thus, our HF echoes at EL's less than $60^{\circ}$ seem to be caused by the rather "isotropic" target. This target might be also sensitive to vertical and oblique beams with EL's larger than $60^{\circ}$, as observed by Kelley et al. (2002) using an HF sounding system. The SuperDARN radars cannot detect echoes with $\mathrm{EL} \geq 60^{\circ}$ where the antenna gain is extremely low; if the vertical sensitivity were not 


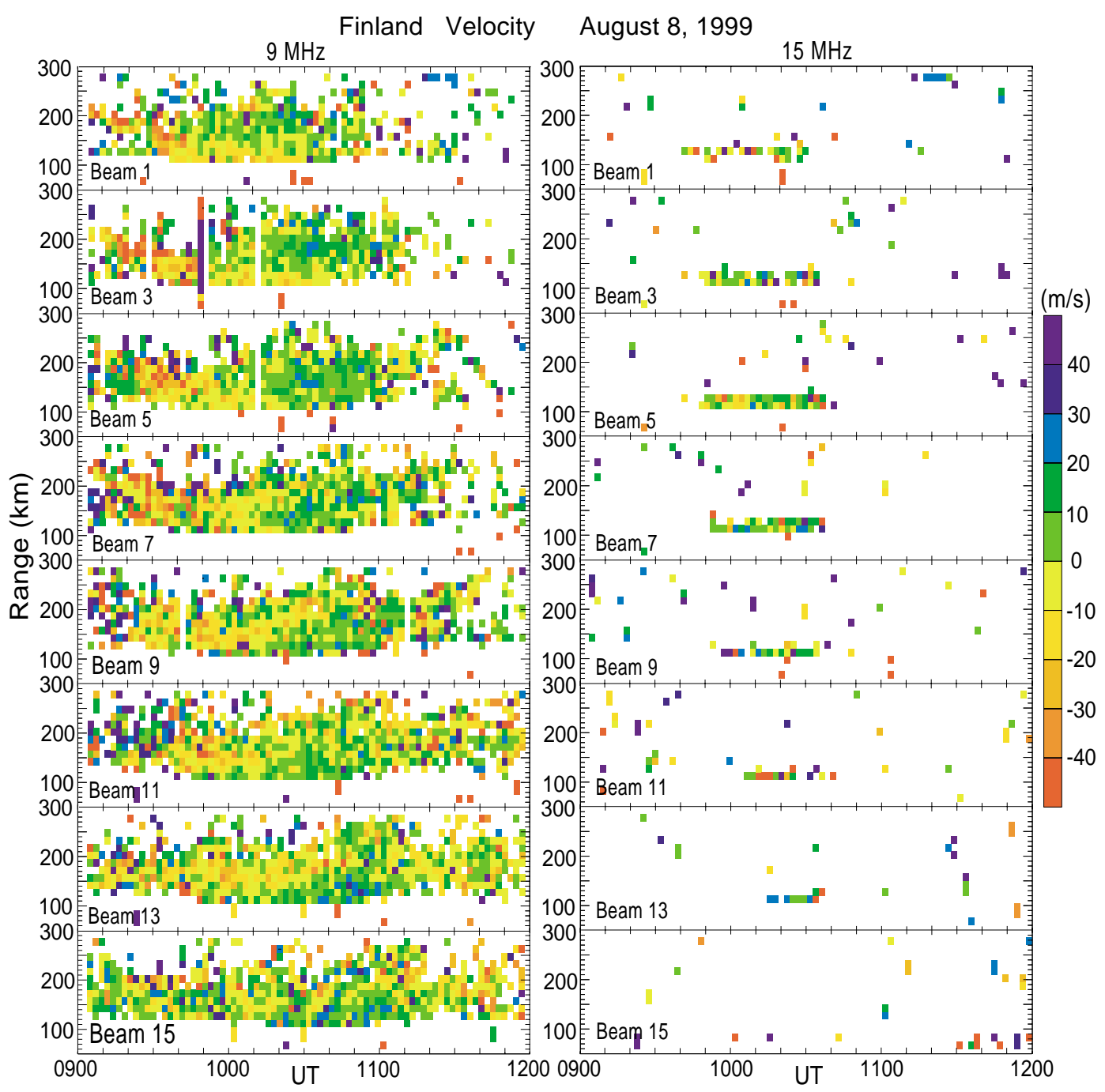

Fig. 6. Time and slant range distributions of line-of-sight Doppler velocity at (left) 9 and (right) $15 \mathrm{MHz}$ on eight beams (beams 1,3 , ..., 15). Positive (negative) sign means motion toward (away from) the radar.

poor, PMSE would be observed at the 2nd and/or 3rd range gates $(75-105 \mathrm{~km})$ of the Finland radar.

The HF echo range and power depend on radar frequency (item 4). In explaining this fact, we take into account factors such as wavenumber spectrum of radar reflectivity, aspect sensitivity of scatterers (that is, the scattering is much higher in the vertical direction than from off-vertical) and instrumental effect (antenna gain pattern in the vertical plane). Using a theoretical beam pattern, it was inferred in the previous section that the $9 \mathrm{MHz}$ echoes with EL's of $19^{\circ}-59^{\circ}$ were detected by the main antenna lobe $\left(\mathrm{EL} \simeq 33^{\circ}\right)$, while the $15 \mathrm{MHz}$ echoes had EL's of $36^{\circ}-59^{\circ}$ that are deviated from the main lobe direction $\left(\mathrm{EL} \simeq 23^{\circ}\right)$ : we suggested that the $15 \mathrm{MHz}$ echoes might be also detected with a side lobe ( $8 \mathrm{~dB}$ down) at $\sim 64^{\circ}$. Thus, we suppose the following scenarios to explain the results. (1) The radar reflectivity becomes smaller at higher wavenumber (frequency) (e.g. Cho and Kelley, 1993) to make echoes are detectable at $9 \mathrm{MHz}$ (Bragg wavelength $=17 \mathrm{~m}$ ) but not for $15 \mathrm{MHz}(10 \mathrm{~m})$ with the respective HF main lobe. (2) PMSE may be more aspect sensitive at higher wavenumber (this sensitivity is very high at VHF-UHF; Czechowsky et al., 1988; Zecha et al., 2001); if this is the case, $15 \mathrm{MHz}$ echoes are detectable only at higher elevation angles. Checking these possibilities is not easy, however, mainly because the frequency dependencies of the HF radar antenna gain pattern and hardware system are not well known. Moreover, the HF radar for the current observations had a range resolution of $15 \mathrm{~km}$, corresponding to altitude resolutions of $5-13 \mathrm{~km}$ at EL's of $20^{\circ}-60^{\circ}$. Obviously, these altitude resolutions are too large to reveal the detailed physical processes of the HF-PMSE.

Note that the northward semi-diurnal component of neutral winds, derived from meteor echo observations using the Finland radar, has a maximum of about $-20 \mathrm{~m} \mathrm{~s}^{-1}$ at about 10:00 UT and of $-15 \mathrm{~m} \mathrm{~s}^{-1}$ at about 22:00 UT in July (Arnold et al., 2003). Thus, the timing (09:30-11:30 UT) of our PMSE occurrence seems to be close to the maximum phase of semi-diurnal tide (Williams et al., 1995). 


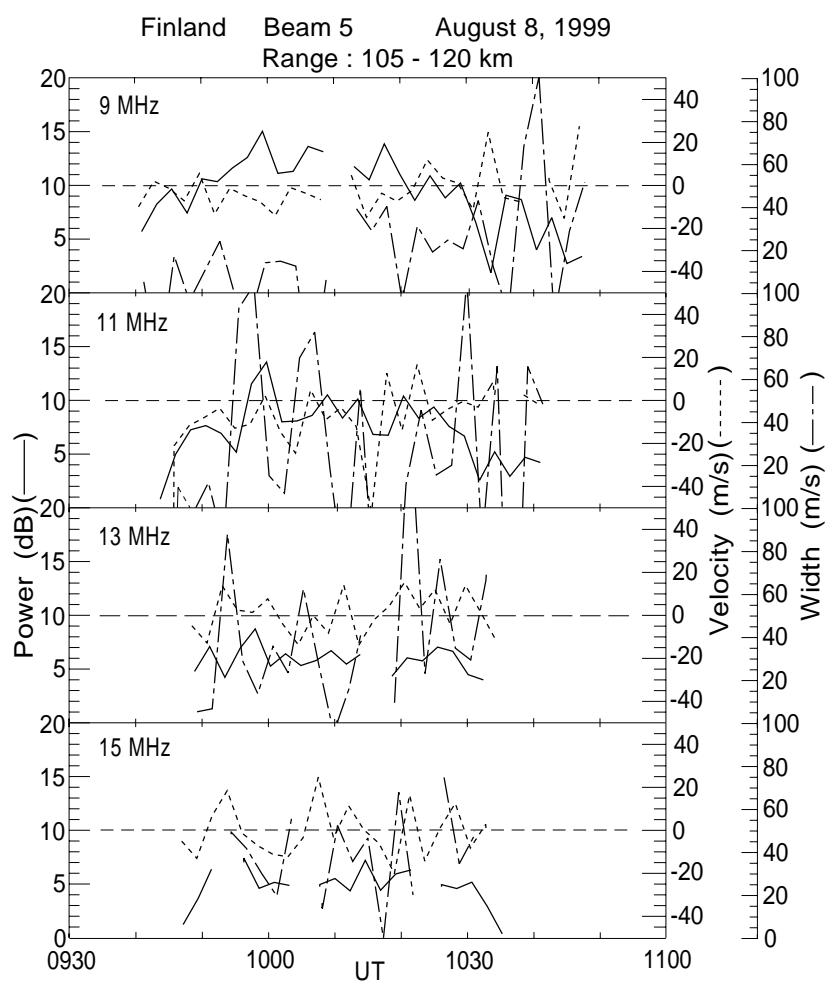

Fig. 7. Time variations of echo power (solid line), Doppler velocity (dashed line) and spectral width (dot-dashed line) at four frequencies at range gate of $105-120 \mathrm{~km}$ on beam 5 .

\section{Conclusions}

Peculiar near range echoes, detected at 9, 11, 13 and $15 \mathrm{MHz}$ with the Finland HF radar in summer, can be identified as PMSE at HF frequencies. This conclusion seems to be supported by concurrent PMSE observations with the Esrange MST radar located at $650 \mathrm{~km}$ north of the HF radar site. HF echo power, Doppler velocity and spectral width fluctuate with periods of several to $20 \mathrm{~min}$, perhaps due to short-period gravity waves. These characteristics are quite similar to those of upper mesosphere summer echoes first detected with the Antarctic HF radars. Angle-of-arrival measurements of HF echoes indicates echo altitudes of $80-100 \mathrm{~km}$, being consistent with the MST-PMSE altitudes. HF echo range and power depend on radar frequency. At present, we have no clear mechanisms to explain this fact and we speculate that this is caused by frequency dependencies of radar reflectivity, aspect sensitivity and the radar hardware system. Obviously, more observations and analyses of HF-PMSE are required in the future to understand the nature of scatterers causing oblique HF echoes.

Finally, as exemplified in this paper, sophisticated SuperDARN operation, using short range resolution $(15 \mathrm{~km})$, first range gate $(60 \mathrm{~km})$ and multiple frequencies, is quite useful for the HF-PMSE study. Many SuperDARN radars have been routinely working under the common mode operation to observe the northern and southern high latitude ionosphere.
We believe that these radars also provide data that are useful for exploring the global climatology, long-term variability and north-south asymmetry of PMSE occurrences.

Acknowledgements. The authors wish to thank the team of the Radio and Space Plasma Physics group at the University of Leicester who constructed, deployed and operated the CUTLASS HF radars. The ESRAD radar is jointly funded by the Swedish Space Corporation and the Swedish Research Council. N. F. Arnold was supported by an advanced fellowship from the UK Particle Physics and Astronomy Research Council and CUTLASS operations were funded by PPARC grant RP16021.

Topical Editor, D. Murtagh, thanks G. Kelly and another referee for their help in evaluating this paper.

\section{References}

Arnold, N. F., Robinson, T. R., Lester, M., Byrne, P. B., and Chapman, P. J.: Super Dual Auroral Radar Network observations of fluctuations in the spectral distribution of near range meteor echoes in the upper mesosphere and lower thermosphere, Ann. Geophysicae, 19, 425-434, 2001.

Arnold, N. F., Cook, P. A., Robinson, T. R., Lester, M., Chapman, P. J., and Mitchell, N.: Validation of D-region Doppler drift winds measured by the SuperDARN Finland HF radar over an annual cycle using the Kiruna VHF meteor radar, Ann. Geophysicae, in press, 2003.

Bremer, J., Hoffmann, P., Manson, A. H., Meek, C. E., Rüster R., and Singer, W.: PMSE observations at three different frequencies in northern Europe during summer 1994, Ann. Geophysicae, 14, 1317-1327, 1996.

Chilson, P., Kirkwood, S., and Nilsson, A.: The Esrange MST radar: A brief introduction and procedure for range validation using balloons, Radio Sci., 34, 427-463, 1999.

Cho, J. Y. N. and Kelley, M. C.: Polar mesosphere summer radar echoes: Observations and current theories, Rev. Geophys., 31, 243-265, 1993

Cho, J. Y. N. and Röttger, J.: An updated review of polar mesosphere summer echoes: Observation, theory, and their relationship to noctilucent clouds and subvisible aerosols, J. Geophys. Res., 102, 2001-2020, 1997.

Czechowsky, P., Reid, I. M., and Rüster, R.: VHF radar measurements of the aspect sensitivity of the summer polar mesopause echoes over Andenes $\left(69^{\circ} \mathrm{N}, 16^{\circ} \mathrm{E}\right)$, Norway, Geophys. Res. Lett., 15, 1259-1262, 1988.

Greenwald, R. A., Baker, K. B., Hutchins, R. A., and Hanuise, C.: An HF phased-array radar for studying small-scale structure in the high-latitude ionosphere, Radio Sci., 20, 63-79, 1985.

Greenwald, R. A., Baker, K. B., Dudeney, J. R., Pinnock, M., Jones, T. B., Thomas, E. C., Villain, J.-P., Cerisier, J.-C., Senior, C., Hanuise, C., Hunsucker, R. D., Sofko, G., Koehler, J., Nielsen, E., Pellinen, R., Walker, A. D. M., Sato, N., and Yamagishi, H.: DARN/SuperDARN: A global view of the dynamics of highlatitude convection, Space Sci. Rev., 71, 761-796, 1995.

Hall, G. E., MacDougall, J. W., Moorcroft, D. R., St.-Maurice, J.P., Manson, A. H., and Meek, C. E.: Super Dual Auroral Radar Network observations of meteor echoes, J. Geophys. Res., 102, 14603-14 614, 1997.

Jenkins, B. and Jarvis, M. J.: Mesospheric winds derived from SuperDARN radar meteor echoes at Halley, Antarctica, Earth Planets Space, 51, 685-689, 1999. 
Karashtin, A. N., Shlyugaev, Yu. V., Abramov, V. I., Belov, I. F., Berezin, I. V., Bychkov, V. V., Eryshev, E. B., and Komrakov, G. P.: First HF radar measurements of summer mesopause echoes at SURA, Ann. Geophysicae, 15, 935-941, 1997.

Kelley, M. C., Huaman, M. M., Chen, C. Y., Ramos, C., Djuth, F., and Kennedy, E.: Polar mesosphere summer echo observations at HF frequencies using the HAARP Gakona Ionospheric Observatory, Geophys. Res. Lett., 29(12), 10.1029/2001GL013411, 2002.

Kirkwood, S., Cho, J., Hall, C. M., Hoppe, J.-P., Murtagh, D. P., Stegman, J., Swartz, W. E., van Eyken, A. P. Wannberg, G., and Witt, G.: A comparison of PMSE and other ground-based observations during the NLC-91 campaign, J. Atmos. Terr. Phys., 57, 35-44, 1995.

Lee, C. C., Liu, J. Y., Pan, C. J., and Liu, C. H.: Doppler velocities obtained by the EISCAT VHF radar and the dynasonde during the PMSE95 campaign, J. Atmos. Solar-Terr. Phys., 63, 193199, 2001

Liu, J. Y., Pan, C. J., and Lee, C. C.: VHF radar and MF/HF dynasonde observations during polar mesosphere summer echoes conditions at EISCAT, Earth Planets Space, 54, 691-698, 2002.

Milan, S. E., Jones, T. B., Robinson, T. R., Thomas, E. C., and Yeoman, T. K.: Interferometric evidence for the observation of ground backscatter originating behind the CUTLASS coherent radars, Ann. Geophysicae, 15, 29-39, 1997.

Ogawa, T., Nishitani, N., Sato, N., Yamagishi, H., and Yukimatu, A. S.: Upper mesosphere summer echoes detected with the Antarctic Syowa HF radar, Geophys. Res. Lett., 29(7), 10.1029/2001GL014094, 2002.

Röttger, J.: Polar mesosphere summer echoes: Dynamics and aeronomy of the mesosphere, Adv. Space Res., 14, (9)123(9) 137, 1994.

Rüster, R., Czechowsky, P., Hoffmann, P., and Singer, W.: Gravity wave signatures at mesospheric heights, Ann. Geophysicae, 14, 1186-1191, 1996.

Williams, P. J. S., van Eyken, A. P., Hall, C., and Röttger, J.: Modulation in the polar mesosphere summer echoes and associated with atmospheric gravity waves, Geophys. Res. Lett., 16, 14371440, 1989.

Williams, P. J. S., Jones, G. O. L., Palmer, J. R., and Rishbeth, H.: The association of polar mesosphere summer echo layers with tidal modes, Ann. Geophysicae, 13, 454-457, 1995.

Zecha, M., Röttger, J., Singer, W., Hoffmann, P., and Keuer, D.: Scattering properties of PMSE irregularities and refinement of velocity estimates, J. Atmos. Solar-Terr. Phys., 63, 201-214, 2001. 